\title{
特集 転換期の社会と家族
}

\section{摇らぐ家族と家族関係諸法}

有地亭

\section{1. 家族の多様化と家族関係諸法}

第二次大戦後の急速な経済の高度成長に伴い産業化、都市化が進行し、その後、経済の低成長期を 迎え、国際競争は激化し、急激な経済、政治状勢の転換を経てきた。乙の間、女性の職場進出む目ざ ましく、徐々にではあるが、男女平等の観念や人権擁護の思想あ定着しはじめた。このような家族を 取巻く状況が著しく変化したてとは当然に家族ないしは家族生活、また、家族に関する意識や家族を めぐる諸法に影響を与えないでは置かなかった。

てれらの状況について概観しておてう。まず第 1 亿、平均世帯規模は 1954 年に 5 人を割って以来、 減少傾向にあり、1987年には 3.19人になっている。そのため、核家族世帯の割合が増加し、1964年の 54.9\%から1987年には 60.5\%に上昇し、乙れに対し、三世代世帯は $15.0 \%$ て 3 分の 1 まで減少して いる。第 2 には、高度成長期に、第 1 次産業から第 2 次、第 3 次産業へ之就業構造が大きく転換した。 全世帯に占める農業世帯は1960年の $22.7 \%$ から1980年までに $9.8 \%$ に減少し、反対に、雇用者世帯は 1960年には $54.6 \%$ 、1980年では $71.8 \%$ で、全世帯の 7 割をてえるにいたった。乙れとともに、女子 の就労屯著しく、とくに、有配偶女子の中で雇用が占める比率は1960年の $8.8 \%$ から1987年には30.6 \%と 3 倍以上の伸び方を示している。

第 3 亿は、出生率が1950年代から低下して抢り、女性 1 人の平均出生児数を示す合計特殊出生率 （女子の出産可能年齢を15 39歳と仮定した場合の 1 人の女性の平均出産児数 ）は1987年 1.69で、西 ドイッについで低い数字である。

第 4 には、離婚率は1963年から1983年まで一貫して上昇傾向にあったが、その後やや低下し、1986 年には、1.37になった。離婚率が上昇し続けるかどうかは予断を許さないが、最近の価值観の多様化、 離婚をマイナスイメージでみない離婚観、結婚観の変化などを総合すれば、多少の上下はあるが、全 体としては減少傾向をたどるといえる要因はない。いずれにしても、離婚した夫婦の約 7 割には子ど もが抢り、母子世帯家庭中の離別家庭の割合も1959年の48.6\%から1985年の50.6\%へ、父子家庭中の それも1971年の $7.4 \%$ から 1985年の $9.9 \%$ \%ずれも増加している。これに、再婚家庭や家庭内離婚 や未婚の母の家庭も加わって家族は多様な形態になっている。

第 5 には、離婚についての意識が1988年12月の朝日新聞の調査 [朝日新聞, 1989.1.1]では、「結婚相 手とうまくいかないときは、離婚してあよい」という考えと「そうは思わない」が45\%ずつで 2 分さ れている。「離婚してあよい」は若い世代ほど高く、30代後半で、肯定する者が増え、11大都市では 肯定派が 5 割をこえる。1988年 4 月の毎日新聞の調査 [毎日新聞, 1988.5.4]です、「あなたは現在の 
摇らぐ家族と家族関係諸法

配偶者と離婚したいと思ったてとがあるか」について、離婚を考えたてとが「よくある」人 $4 \% 、$

「たまにある」人 $29 \%$ で、3 分の 1 の夫婦が離婚を考えたてとがあるという結果である。男女別では、 男性 $25 \%$ 、女性 $41 \%$ が離婚を考えたてとがある人で、とくに、女性の30～50代で各 4 割と多い。

第 6 には、結婚観について、前掲の朝日新聞調查で、「夫婦は一心同体の方がよいと思いますか。それ とも、夫婦といえどあ互いに干渉しない部分があるべきだと思いますか」の問いに対し、60\%が「干渉しな い部分があるべきだ」と答え、「一心同体の方がよい」は $36 \%$ にすぎない。「干渉せず」は戦後育ち の20４0代では 7 割前後と高く、どの世代とあ男性より女性が高く、とくに、30代前半の女性は77\% と多い。

てれらをみると、夫婦はそれぞれが自立して相手方からやたらに干渉されるのを好まず、そのかぎり では、夫婦はべったりではなく、その絆も強くないというのが若い世代に多い。若い世代で結婚、離 婚に対する考え方が確実に変りつつあるといえよう。

てれらの变化が家族に及ぼす影響について、もういちど概括すればつぎのようになる。

雇用者家族の圧倒的な増加はそれまで家計と経営の未分離の農業家族から、一变して、サラリーマ ン社会化の現象が進み、賃金生活が一般化し、家族は労働者再生産のための単位であるととあに、消費 財の市場にむなり、企業への従属を一層深めている。乙の家族は、個人にとっては生活の場であり、 ストレス経済のいこいの場であって、サラリーマンの家庭という同質の生活様式が一般化する。また、 平均賃金が相対的に上昇するに伴い、1969年頃から、いわゆる中流意識が多くなり、80\%をてえるよ うになる。

核家族の増加は平均寿命の伸長 ( 男子75歳、女子80歳をてえる長寿 ) とあいまって、子の家族と老 親家族の分離をますます進行させ、60歳以上の夫婦世帯、高齢者単独世帯を生じ、老人問題が社会問 題になってきた。とくに、高齢者の介護をどうするかが問われ、三世代家族など、家族のあり方が問題に なるし、また、嫁としゅうとめの地位の逆転の中での老人介護が顕在化してくる。

妻の就労の機会の増大は、家庭内の夫婦の性別役割分担体制の見直しを迫り、家庭外での児童の保 育問題を深刻化させる。平均寿命の伸長と子の出産率の低下は相続の機能を变えた。被相続人の死亡 の時点で、子どあの相続人の年齢が40 50歳に達している場合に、相続財産が相続人の生活を保障す るという機能はなくなり、相続財産は被相続人みずからのために活用され、相続の機能を一変させる。

最後に指摘できるのは、離婚の増加ととあに、個人の価値観が多様化し、自由に選択した生き方を しょうとする態度をとる者あ多くなっているてとである。その結果、家族形態あ多様化し、核家族が 主流を占めるけれどあ、母子家庭、父子家庭、再婚家庭、未婚の母の家庭、単身者世帯など、高齢者、 若年者をとわず、家族形態は多彩になった。

乙れまで、家族法は家族の形成、維持、解消に関する法規定をおいたが、その前提にはモデルとし ての家族があった。明治民法の、そのような家族は武家社会の家をモデルにした「家」制度を定めた。 しかし、当時、広範囲に存在していた農家は、家計と経営が未分離の大家族で、家長=戸主により統 率された無償労働力によって集約的経営を行い、生産性を高めた点で、「家」制度は農業の発展に好 都合であった。

戦後、改正された民法の家族法は夫婦と子からなる近代的家族をモデルとした。産業化、都市化の 
結果生じたサラリーマン社会での核家族は経済の高度成長に適合した。核家族は移動性に富み、良質 の労働力の供給源にもなったし、また、大量に販売された商品を消費する場にすなった。

そもそも、家族は道徳、倫理、宗教、慣習、モーレスなどの社会規範からの規制を受け、家族法は それらの社会規範の一部を内在化させた、家族に対する諸々の社会統制の手段の中ですっとも強力 で、組織的なあのである。民法の立案者は明治民法の場合にあ、また、戦後の家族法改正の場合であ、 家族の到達すべき法的モデルを想定した。それは、明治民法の場合には「家」制度であり、また、戦 後の家族法改正では、民主化された近代的小家族である。立案者の意図は家族の法的モデルをあっ て家族秩序を先導し、家族秩序を变革しょうとするとてろにあったと思われる ${ }^{(1)}$ 。したがって、家族 の法的モデルと現実の家族との乘離が著しいときには、法改正が企図される。1919年、わが国固有の 淳風美徳の「家」秩序を維持するために、臨時法制審議会により答申された「民法親族編中改正要綱」 （1925年）と「民法相続編中改正要綱」（1927年）の改正がそれであるが、いずれあ、改正の意図と は別に、現実の家族に合せた改正案であった。戦後では、家族法の一部改正はなされたけれどあ、特 別養子制度の導入 ( 1987 年) 以外には、大きな改正すなされず、むしろ裁判例などでは、近代的小家 族の法的モデルを維持しようとする努力のみが目につく(2)。前述のように、今日の現実の家族は多様 なあり方を示しているため、そのような多様な家族に対して、家族法のみによって十分に対処できる あのではないので、家族法以外の他の多くの特別法によって規制がなされているし、また、家族に関 する諸政策も策定され、さらに、新たな家族の状況から生じた社会規範によっても規制を受けている。

てのように、激しく变動する今日の社会状勢の中で、家族法の領域では、法や他の政策、社会規範か競: 合、交錯するため、数年前から、フランスの民法学者ジャック・コマイユ氏 ( Jacques Commaille) などにより『家族に適応される社会諸規制の社会学』(Sociologie des régulations sociales appliquées à la famille $<$ S.r.s.f.>) の研究グループが形成され、離婚、家族の正義、女性 の地位、結婚、家族間の交換、子どあの地位などについて、研究を開始している(3)。家族法は社会変 動に対応して、それらを完全に反映したものではなく、家族法や他の社会規範の複合体である制度自体 の発展に応じて、家族法そのものあ変容するという認識に立って、家族構成員の行動に対する諸々の社会 的期待、規範を支持する諸々の価値観、規範同調の諸々の現実的可能性など、家族の様々の領域にお いて機能している社会規範の構造を明らかにしようとするあのである。

わが国に抬いては、家族法社会学す漸く最近になって、てのような研究領域をす目指そうとする動 きがある。

\section{2. 社会構造の転換と価值観の変化}

経済の高度成長はすでに述べたように、第 1 次産業の衰退、第 2 次、特に第 3 次産業の伸長という 就業構造の転換をむたらした。今日の消費社会では、サラリーマン家族を対象にして、大量の商品が 販売され、クレジットなどに依った消費型の生活様式が一般化するに応じて、家族の日常生活も変化 した。それと同時に、社会生活での価値観む変貌した。

かっての資本主義の精神は禁欲的なプロテスタンティズムからその職業倫理を継承したといわれ、 勤勉、倹約、禁欲が追求すべき徳目とされた。しかし、今日では、そのような徳目は背後に退き、仕事 
摇らぐ家族と家族関係諸法 を生がいとするのではなく、生活をエンジョイするために働く、仕事よりあ結婚や家族にみずからの 幸せを見出そうとする傾向が顕著になっている。

すでに述べたように、経済的繁栄の中で、いまの生活に満足している人は 6 割をてえている。「あ なたにとって一番大事なあのはなにか」で、朝日新聞調査では、1984年以降「家族」がトップで、そ の傾向はさらに強まった。乙の変化は男性の「仕事」に対する評価にあるとされ、1978年調查では、 男性の14\%が一番大切なあのとして「仕事」を挙げたが、1987年には $8 \%$ に減少した。特に、働き盛 りの40歳代で大幅に減ったとされる [朝日新聞, 1988.2.6:「日本人の素顔」(4)]。妻も同様であって、1988 年調査で、夫の夕イプとしては、「家庭本位」と「仕事本位」のどちらを重視する人がよいかでは、 前者が46\%、後者が26\%で、家庭重視が圧倒的に多い。家庭本位は女性（44\%) よりむしろ男性 (48 \%) に多く、若い世代ほど支持が高く、20代の男性は 7 割以上が家庭本位である [ 朝日新聞, 1989.1.1 ：「日本人の家庭観」］。「人生の目標」についても、「世の中をよくする」は1984年の調査では、7 \%だったが、1987年であ6\%とほぼ横ばい状況である。「人生を自由に楽しむ」といった私生活にか かわる意識への関心が圧倒的で、特に、事務職層や若むのにての傾向が強いといわれ、1987年には、 20歳代前半で、「世の中をよくする」がわずか $1 \%$ 「すぎない [ 朝日新聞，1988.12.13 :「日本人の素顔」 (8)]。

若むのを中心として関心が自分ないしは自分の周辺の家族に向っている。乙のように、個人が結婚 や家族に幸せを求め、家族を大事にする傾向は、西欧に抬いても指摘されている。フランスの家族社 会学者アンドレ・ミシェル女史 ( Andrée Michel ) は西欧においても、若あのを中心に家族に対し て満足する、幸福主義（ eudémoniste）が顕著であると指摘する［Miche1, 1980］。

3. 親、とくに母親の子どあの教育に対する関心の増大

若むのを中心に家庭重視の傾向が顕著であるとすれば、核家族内で、夫婦はなにに関心をむち、情 熱を傾けているのか、である。

各家庭では、子ぞむの数が減少し、相対的に所得も増え、また、父母が高学歴化し、しかむ、学歴 社会が牢固として存在している状況の中で、親、特に、母親が子どあの教育に熱心である。

第 2 次ベビーブームの影響で、1986 92年までは、18歳人口が増え、最高は 2,052 万人にあなる。 そのため、大学進学人口は過去最大の 64 万 3,000 人にあなり、進学率は低下しても進学熱は落ちてい るわけであなく、受験戦争は激しいと予測されている [総合研究開発機構, 1987：923］。

親には大学、しかむよい大学を出なければよい就職ができないと思っている者も多いし、大学自体が 社会に出るための一つの通過儀礼化しているため、大学受験戦争は激化している。上流階層の母親に は、よい私立大学の幼稚園に子どあを入学さすてとに狂奔し、また、中流階層のサラリーマンの家庭 であ、よい中学・高校への受験競争にフィーバーする母親が数多く登場している。夫が転勤してあ。 子どあの受験戦争のために、母親は子どあと東京に残り、父親のみが単身赴任するケースとか、ある いは、子どあのために夫を地方に残して母子だけで東京周辺に引越したケース、あるいは、母親が付 き添って子どもを幼児から塾に通わせるケースとか、子どあの教育に情熱を傾注する母親の例は枚挙 にいとまがない。この背景には、ゆとりの多少ある層で、母親が高学歴化し、子の数が少なくなり、 
受験戦争は激化する一方で、よい大学を出ればよい就職ができるという学歴社会は解消されない状況 があるので、母親が子の教育にひまと金をかけるところにある。

上野干鶴子氏は 4 年ほど前「結婚あレジャーだし、何よりあっとテマヒマのかかるレジャーは子育て である。私事化の極限にあって『親の勝手』でやる子育ては、あっとあぜいたくなレジャーとなる」 と現代の母親による子育てを挪揄しながら、将来を展望し、「ダブル・インカム型のファミリィ・セ ッティングの中で子育てというテマとヒマのかかるレジャーを実践しょうとしたらーその上、妻の就 労は、子どあの社会化費用のために、今や不可欠としている一家族はどう変わらなければならない か」と言い、女性はあはやフルタイムの母親にならず、都市雇用者核家族で、他の女手むないとすれ ば、夫を育児に引きこむほかはないと、育児への夫婦共同参加を説く［上野，1985：131-132］。

わか帼では、将来の大学進学を見据えたうえでの中学受験の過熱という原因のため、首都圏全体で10人に 1 人の小学生が中学受験を目指すという現象が出てきている。とてろが、西欧に㧤いては、かなり以 前から 5 歳で幼稚園に入園する前の $2 \sim 5$ 歳の幼児に教育を受けさせようとする母親が増えている

[ Chamboredon, et Prévot, 1973:295-335]。その事情はこうである。

フランスでは、6歳で小学校に入学するが、それ以前の 2 ～歳が社会化、知的発達のための就学前教育 の段階と位置づけられ、《幼児期》( prime enfance).と称される。2 5 歳の子どあの66\%が公私 立の就学前教育 (幼稚園、小学校・中学校付属の幼児学級、小学校付属の幼児セクション) 觉けて いる。その率は1964年の48\%から1971年には66\%になったが、特に目立つのは、低い年齢層での入園 者の増加で、1963年と1971年を比較すると、2 歳児では 2 倍になり ( $9.7 \%$ から18\%)、3 歳児では 50\%の増加であるが $(40 \%$ から61\%)、4 歳児では70\%から87\%、5 歳児は75\%から95\%にとどまる。

それでは、なぜ小学校就任前の教育を受ける幼児の数の増加と低年齢化が生ずるのかの点については、 2 つの事由が挙げられる。

1 つは、就業構造の転換で、都市居住雇用者核家族が増加し、しかす、夫婦とも働きも定着し、と りわけ、女性の結婚後の職業活動が本格化したため、育児のために職を辞めるてとがなくなった。従来、育児 は家事とともに母親の手に委ねられてきたが、家事は夫と共同にできるけれどあ、育児については、自 分あ夫む、また、他の家族構成員の手を借りるてとあできなくなってきた。そうすると必然的に、家 族外の施設に幼児を預けることになるが、その費用を夫婦が働けばなんとかなる状況にあるというこ とである。

あう 1 つは、2〜 歳の《幼児期》について、教育心理学の上では、ての時期の教育が子どあの人 格形成や知能の発達に重要な影響を与えるという考え方が普及したてとである。その結果、母親の生 理的、愛情的な看護の対象としての《赤ん坊》という時期は出生直後のごく限られた乳児期だけに設 定されることになり、また、幼児期の子どあの社会化により子どあの取扱いについて、父親む母親を 一緒に参加するようになり、従来、母親專業になっていた母親の役割に変化が生じた。

この問題は、わが国と比較した場合に、母親が子の教育に懸命になる点では同じであるが、わが国 の母親は専業主婦か、あるいはパート・アルバイトの主婦であり、また、その教育あ中学受験という 小学生を中心としたものである。しかし、若い世代に、パート・アルバイト以外の有配偶者女子の雇 用者が増加したときに、フランスと同じような就学前の幼児教育の問題が出てくる可能性がある。 
摇らぐ家族と家族関係諸法

1987年の有配偶者女子の有業率を末子の年齢階級別にみた場合に、末子が $0 \sim 5$ 歳の乳幼児の場合の 有業率は低いが、パート・アルバイト以外の雇用者の割合は高く（ $45.8 \%$ 、ちなみに末子が 6 ～11歳 の場合には、33.1\%である）、無業者の就業希望意識をみてあ正規の職員・従業員を希望する者の割 合が高い [労㗢省婦人局, 1988：69]のあ、若い世代を中心に、主婦労働が変化しつつある兆しなのかも しれない。

\section{4. 家族政策の諸問題}

最近、欧米に拈いてす、わが国であ、家族政策に関する研究が活発で、すぐれた研究が出ている(4) 家族政策については、種々定義がなされているが、広く見て、公権力によって家族自体掞よび家族 秩序の形成・維持・発展のための諸条件にかかわる政策の全体と言ってよいと思う。乙の家族政策は 重盢的構成をとっており、基底には、家族法があって一定の法的モデルと家族構成員の遵守すべき行 動様式の枠組を掲げる。しかしながら、ての家族の法的モデルに包摂されず、その周辺に生ずる家族 問題に対しては、家族法では対応できないため、特別法を制定し、それによって対処せしめている。 最近、家族のあり方が多様化しているので家族に関係する特別法む非常に多くなっている。てれらの 個人や個々の家族を対象にする政策のほかに、政策主体者が望ましい家族の状態について一定のビシ ョンをあち、その方向に家族を導くように積極的に関与しょうとするてとあある。

このような家族政策の動向について、庄司洋子氏は経済の高度成長期と低成長期とでは異なった方向 をとるととをつぎのように指摘する。1960年代の経済の高度成長期には、家族機能についての自助の 限界を認め、家族機能の脆弱化を補完する政策の必要性から、家族が援助の対象にされ、社会保障、 社会福祉を拡充する方向をとる。乙れに対し、1970年代以降の低成長期には、施策の重点化、効率化、 適正な費用負担という名のあとにすすめられる政策体系の再編の中で、家族が社会保障、社会福祉の受け 皿として政策を補完・代替する機能が期待されるようになったと分析する [庄司, 1986 a : 137-138, 1986 b : 154-］。低成長期に入ったが、老人世帯が急増し、女性の就労が増え、老親扶養と子の保育、 しつけは家庭の責任と説かれ、自助努力による日本型福祉社会の実現が目指されている ${ }^{(5)}$ 。政策のま にまに摇らぐ腺族の状況を知ることができる。

てれまで、わが国の家族法立法や家族政策の分析は立法者が理想とする法的家族像や家族法秩序を 抉り出し、その国民への浸透にいかに努力をしているかに重点があったし、また、政策主体者が 家族の機能を補完、強化したり、あるいは家族の自助に依存したりする態様について、社会経済の変 動に応じてどのように変ったかを明らかにするのが主流である。

今日の雇用者家族を見た場合に、かっての家長によって支配されていた「家」制度と異なって、家 族のイデオロギーの強化、補強といっても、その教育的機能に期待ができるような状態ではない。むし ろ、てのような意味での家族構成員に対する教育は公教育で行われており、その影響の方がはるかに 強い。

今後の家族関係法や家族政策の研究では、ある家族関係法や家族政策の施行によって、家族ないし 
個人にどのようなインパクトを与え、そのために、個人の人権が擁護されているのかいないのか、人 権が毀損されるような状態であれば、諸法の改正、政策の転換、補強にはどんな方法を講じなければな らないか、のレベルまで立ち入って検討する必要があるのではないかと考える。

\section{5. 家族の財産に対する意識の変化}

最近の地価の異常な高騰により、宅地、家屋の資産としての重要性は増加したが、普通の雇用者家 族にとっては、その居住しているいわゆる持家だけというのがほとんどであって、資産は預眝金、生 命保険、有価証券などの金融資産が中心になる。『昭和62年版国民生活白書』によれば、1 世帯当た りの金融資産の蓄積動向について、眝蓄残高でみると、1970年当時 160 万円であったが、1986年末に は 910 万円で、16年間で約 6 倍の残高である。年齢別でみると、50歳代 1,150 万円、60歳以上 1,395 万円で50歳以上の世帯は 1,100 万円をてえている。資本主義の発展とともに、不動産から債権の優位 へ資産構成の変化が反映したあのであるが、ての変化はかって家族を支えていた家産を崩壊せしめ。 家族の物質的な存立基盤を大きく変えてしまった。とりわけ、生活保護法 ( 1950年 ) や厚生年金保険 法 ( 1952年)、国民年金法 ( 1959年 ) などの各種年金法が施行され、さらに、児童扶養手当法 ( 1961 年 ) の実施により、従来の家族構造や家族形態を変更することになった。乙れまでは、家産に依拠し て若むのの家族と老親が同居し、老親が若むのによって金銭扶養を受けていたが、そのようなケース は少なくなった。

都市居住雇用者核家族が一般的になり、老親たちは前述の年金などの金融資産で自立できるとなる と、65歳以上の高額者夫婦世帯、高齢者単独世帯が多くなり、とくに、東京・大阪の大都市圈で 多いし、また、鹿児島、高知などを含む九州、四国、中国、北海道という過疎地域を含む非大都市圏 にも多い [人口問題審議会・厚生省大臣官房政策課・厚生省人口問題研究所, 1988：115]。年金などの確立 はこのような高齢者核家族を産む原因の 1 つにあなったし、また、1985年の国民年金法改正によりサ ラリーマンの専業主婦の年金権が確立され、「老後む夫次第」という状況から妻が解放されたのも、

多様な家族を生ずることに寄与する。てれらの事態は、子どあたちの雇用者家族と親たちの高齢者世 帯が分離する結果になり、親子が同居して老親を介護するてとがますます困難になり、深刻な高齢者介 護問題を社会に投げかけている。

あう 1 つの家族の財産問題は、平均寿命の伸長、子の出生率の低下、土地の高騰などにより相続の あつ機能が変ってきたてとである(6)。

1980年、内閣総理大臣官房老人対策室により60歳以上の在宅老人で、不動産を所有する者の意識調 查が発表されたが、それは相続に関していままでみられなかった現象を示した。「子に相続させる場 合にあっとあ望ましい形態はどれを考えているか」という質問に対し、長男に継がせるという長子相 続を支持する者が43.2\%、ついで、面倒を見てくれる子に多く継がせるという対価相続を支持する者 が39.1\%、一番少ないのが子どあに平等に分けるという均分相続を支持する者で、1 $12.1 \%$ \%すぎない。 対価相続意識が60歳以上の者にかなり多いととと、民法の定める均分相続に人気がないととの $2 つ$ が注目すべき結果である。 
摇らぐ家族と家族関係諸法

その後の相続に関する調査をみると、対価相続を支持する者が非常に増えている。1986年の総理府 広報室の「長寿社会」調査（20６0歳を調査対象者にする）あ、「親の面倒をみる子どあが相続する」 と答えた人が $58.2 \%$ 、親の面倒をみる、みないにかかわらず、均分に相続するのが $19.5 \%$ はずない [総理府広報室, 1987:28］。さらに、1988年の毎日新聞調查 [毎日新聞。1988.5.4 ] でも、「両親が亡 くなった場合、財産はだれが優先して相続すべきか」について、「長男でなくとも家族の中で 親の面倒をみた人」が48\%、「家族に限らず老後の面倒をみた人」が $11 \%$ 、「老後の面倒をみてくれ た病院や福祉施設など」が $1 \%$ で、相続人に限定しなくて対価相続意識をむつ者が 6 割もいる。「子ど 屯全員に平等に分ける」が25\%、「長男」が12\%と非常に少ない。

てれらをみると、子の相続について、対価的意識が漸次明確になってきたし、また、戦前からずっ と、わが国では遺言を活用する者が少なかったが、最近では増えてきているてとあ新しい現象である。 この対価相続意識は大都市に居住するサラリーマンやその主婦の中に年齢をとわず多いとされている。 被相続人の面倒をよくみてくれた相続人が多く財産を取得するというのが対価相続意識であるから、 相続というあのが相続人的生活保障の問題ではなく、被相続人的扶養の問題とからめて考えられるよ うになってきたということを意味する。

てのような相続に関する意識の変化にはつぎのようなととがその背景にあると考えられる。近時の 国民の平均寿命の伸長は著しいし（1985年には、男子が74.8 歳、女子が 80.5 歳）、また、出生率が低 下し、国民のライフ・サイクルも大きく変った。1985年の平均家族周期で、父親が死亡する時の子の 年齢は長子が 47 歳、末子 42 歳、母親の死亡時には、長子が56歳、末子が53歳になる 以口問題審議会・ 厚生省大臣官房政策課・厚生省人口問題研究所, $1988: 89]$ 。

乙れらの状態を前提にすれば、父母死亡の際に、子どあは40歳をてえており、それらの相続人が父 親の遺産によって扶養を受ける必要すない。むしろ、父親が死亡した時期には、相続人である子の子、 すなわち、被相続人の孫が自立する時期になっている。祖父母の遺産は孫の自立のために役立ち、相 続人はそろそろ定年を迎える時期に来ていて、遺産は相続人たる子に関するかぎり、あまり役に立た ない。いわんや、相続財産は相続人の生活保障に役立つということなどは子に関するかぎり神話に等 しい。

これまで、相続の機能が相続すう相続人品問題としての生活保障が考えられ、遺留分の意義が論じ られてきたが、いまや、相続は相続される方、すなわち、被相続人政邀として登場してくる。

被相続人の方は平均寿命が伸び、60歳の定年後、20、30年間の長期間自活しなければならないために、 退職金や各種年金はほとんど使い尽し、死期が迫る頃には、居住している宅地、建物のみが唯一の財 産ということになる。しかす、被相続人は高齢なるがゆえに、介護などを子から受けるようなととにな るならば、面倒を見てくれた子に遺産の宅地・建物を与えたいという意識をむつようになる。てのような ことが、対価相続意識が顕著になって、相続の機能む従来と違ってきた点である。

6. 家族法裁判例のあり方と家庭裁判所の役割

すでに見たように、最近の調査によれば、結婚観む離婚観も若い層を中心に変ってきた。離婚に対 して挫折とか、失敗とかの暗い、罪想感をあってみられなくなり、また、結婚についてあ、夫婦のそ 
れぞれの自立を認め合い、お互い干渉しない部分をあち、べったりの一心同体ではないという考え方で ある。

戦後40年以上経ち、経済の高度成長の過程で、家」制度が崩れ、核家族が定着していくなかで、家 族に関する意識も少しずつ変ってきたし、それを反映するょうな家事紛争あ生じている。

しかしながら、裁判所は概して夫婦一体の婚姻の法的モデルを維持しようと腐心している(7)。

有責配偶者の離婚請求を認めないという最高裁判決が昭和27年 2 月19日 [民集 6 巻 2 号 : 110 ] 亿 出されて以来、積極的破綻主義への離婚法改正が西欧において1970年代になされたにあかかわらず、35 年間にわたり、かたくなに守り続け、最高裁判所大法廷は昭和62年 9 月 2 日判決 [民集 14 巻 6 号 : 1 ] によって、(1)別居が相当の長期にわたる、(2)夫婦間に未成熟子がいない、(3)離婚によって相手方配偶 者が精神的・社会的・経済的に苛酷な状態におかれない、という要件が満たされる場合にかぎり、有 責配偶者の離婚請求を認めるべきであるとして破棄、差戻した。

このケースあ、夫が他女と同棲し、婚姻関係が破綻した後に36年も経っている。この夫は他女と同 棲し、2 人の子をもうけ、その子を認知しており、重婚的内縁関係に基づく家庭があり、事業にも成功して 安定した生活を営しでいる。妻は形骸化した戸籍上の妻たる身分をむつが、実兄の家に寄寓し、資産む なく、ほそぼそ人形店で働いて生活していたが、その勤めむ定年でやめている。その後、有責配偶者 からの離婚請求を認容する判決が、別居期間30年、22年、16年めのケースについてあ相ついで出され た [最高 ( 3 小 ) 判決昭和62.11.24, 判例時報, 1256 号 : 28 , 最高 ( 2 小) 判決昭和63.2. 12, 判例時報, 1268 号： 33, 最高 ( 1 小) 判決昭和63.4.7, 判例時報, 1293 号：94]。

形骸化しているけれよ゙、その法律婚を保護するのか、それとす、重婚的内縁関係に基づく家庭を認 容するのかで、最高裁判所は後者を選択する態度をとったことになる。

最高裁判所が前者から後者への態度を転換したのは、1つは、婚姻の本質をあって双方の意思に基 づく精神的、肉体的な共同生活にあるとし、共同生活の実体を失い、戸籍上だけの婚姻を存続さ せるのは不自然とし、結婚の内実に目を向けるようになったてとである。あう 1 つは、男女の結合関 係が多様になって、法律婚、そうではない婚姻という形態の区別よりあ自由意思に基づく当事者の選 択の方を重視したてとである。つまり、夫は妻に対する婚姻義務に違反して婚姻を破綻させた責任が 問われ、その意思によらない婚姻が、強制されるのではなく、自由に選択した婚姻の方が認められたてとにな る。婚姻とか、離婚とかの自由は当事者の意思と人格に深く根ざしたあのであるため、そのような内面的な領 域を尊重するてとが要請されてきたということができる。他方に括いて、3つの条件の下に社会正義 に反しないという枠内ではあるが、離婚を法的に強制される妻の自由をあ考慮しなければならないと 思われる。すくなくとあ、財産などその他によって十分な経済的保障がなされることが必要であろう。

あう 1 つの問題は、最高裁判所をはじめ下級審む終始一貫して認めているとてろの、上のケースで言 えば、法律上の妻が夫の相姦者である他女の不貞行為に対する慰謝料請求を認容しているてとである。 すなわち、判例は一方配偶者との不貞行為を理由に、他方配偶者が不貞行為の相手に不法行為による 慰謝料を請求するてとができるというのである。判例は、「夫婦の一方の配偶者と肉体関係を持った 第三者は、故意又は過失がある限り、右配偶者を誘惑するなどして肉体関係を持つに至らせたかどう か、両者の関係が自然の愛情によって生じたかどうかにかかわらず、他方の配偶者の被った精神上の 
摇らぐ家族と家族関係諸法 苦痛を慰謝すべき義務があるというべきである」と判示する [最高 ( 2 小 ) 判決 昭和54 3.30，民集 33 巻 2 号 : 303 ]。

てのように、夫婦間における貞操義務違反に加担する第三者の行為をもって不法行為とするかぎり で、法律婚の夫婦間の貞操義務は第三者による侵害からは保護される。しかしながら、不貞行為を犯 した配偶者の貞操義務違反行為を不問にしながらむ、第三者に対して無条件に慰謝料を請求すること ができるというのは、わが国において、とりわけ判例が法律婚を擁護する立場を堅持しているととの 結果にほかならない。西欧においては、乙の種の訴訟はほとんどみられないとされており[人見, 1980 ：234] 、そもそも夫婦間の性関係も自然の自発的な合意に基づく行為であって、夫婦間で性交渉を 請求する権利や義務があるといら問題ではないからである。星野澄子氏が、判例で守られているのは、 婚姻制度の中の「夫の座」「妻の座」であって、「制度の外で新たな愛を発生させた者( 相姦者と呼 ばれる）に対し、家庭破壊者として法的・社会的に制裁を与えていくという構造になっている」との 指摘は正確である [星野, 1987：100]。

判例法上、有配偶者の離婚請求が認容されるようになって、不貞行為は制裁に值する婚姻義務違反 行為とはみなされなくなった以上、それとの関連からあ、配偶者の一方と性関係をむった第三者の行為を 一律に不法行為になるとするは均衡を失する。婚姻の内外をとわず、性関係をすつか否かは個人の人 格に結びついた自由な意思の選択に委ねられる領域で、法の介入が許されない問題であるからである。

最後に、1987年に、刑事事件として、夫について妻に対する強姦罪の成立を認める下級審の判例が 出た [鳥取地判決昭和61.12.17, 判例タイムズ 624 号：25, 広島高松江支部判決昭和62. 6.18, 判例時報 1234 号：154]。乙れらの判例は当時の新聞でも、大きく取上げられ、夫婦間でも夫婦関係が破綻ない しは実質的不存在の場合には、相互に性を求める権利義務を考慮する余地がないとして、夫婦間のレ イプの成立を認めたものである。夫婦でも、当然に性を求める権利が存在するというのでは、性はそ れぞれの自由意思に基づく選択によるものであることを判例が認めたとてろに意義がある。前述の最 近の世論調査で、夫婦間でも、自己決定権に委衫られた、怙いに干涉しない部分があることを望む 結婚観とす軌を一にするといえよう。

最後の法的問題は、ほとんどの家事事件は当事者の協議に委ねられ、協議ができない場合には、家 庭裁判所の調停や審判で解決され、通常の民事事件之そのあり方が異なるという点である。

家族法は、婚姻、離婚、養子縁組などの重要な身分行為の形成、解消、婚姻費用の分担、扶養の順位・ 程度・方法・遺産分割などについては、公的機関の関与むなく、すべて当事者の合意に委ねている。 それだけではなく、協議離婚の際の未成年の親権者・監護者の指定や監護に必要な手段の決定などあ 未成年の子の代理人としての親の協議に委ねている。協議ができなかったり、成立しない場合には、 家庭裁判所の調停に付されるが、調停も協議の延長で合意を基礎にする。このような構造の場合に、 つぎのような問題がある。

まず第 1 に、前述のような事柄について、すべて当事者の自律に委ねられているのは、当事者の意 思がなによりあ尊重されなければならない身分行為に招いては妥当な解決のようにみえる。しかし、 そのためには、各当事者が自由に意思決定することができる精神的、経済的、社会的な条件 下にあることが必要であり、そのような条件が整備されなければ、力関係が支配し、弱者は相手方の 
不当な請求に屈するという事態あ生じかねない。また、協議は双方が前向きに話し合う姿勢で臨まな ければ、話合いは実りのある結果にはならない。一方の当事者がはじめから拒否する姿勢であれば、徒 に話合いを長引かせるだけである。

第 2 には、離婚の協議や調停では、離婚自体の合意のほかに、財産分与、子の親権者の指定、子の 監護処分、子に対する面接交渉などが同時に解決されなければならない。その場合に、離婚交渉の過 程で、当事者の権利、有利な主張などが、金銭的な価値で評価されて取引に用いられたり、また、金 銭的価值にかかわりないときであ、当事者の思惑や都合とからまされ、取引や駆け引きの材料に用い られる ${ }^{(8)}$ 。勿論、乙れらの駆け引き屯法の枠組内での、協議に委ねられた範囲にかぎられるが、事実上 そのような駆け引きによって決定され、当事者の本当の意思や利益が後退させられてしまう事態にも なりかねない。駆け引きがあまりにもひどいときは、協議不成立ということで、一方の当事者は家庭 裁判所の審判を受ければよいが、そのようにすれば解決は長引いてしまう。

いずれにしても、家族問題について協議、調停ができなければ、離婚などの一部を除いて、家庭裁 判所の審判によって解決が図られるてとになる。とてろが、家族法は、家事審判についての解決の基 準としては、当事者の「その他一切の事情」を考慮して解決すべしとする条文がほとんどである （たとえば、760条・768条 3 項・879条など多い）。乙のように、適用される規定が白紙条項ある いは一般条項である場合には、家事審判官の果たす役割は非常に重要になってくるし、民事事件の裁 判官の役割とも異なってくる。民事事件の裁判官は事実関係を評価し、それに民法の規定を適用して結論を 導き出すのであるが、家事審判官は法によって許容された枠組内で、裁量権を行使し、当事者の正当 な利益とか、未成年の子の利益とかを評価して最良と判断する決定を下すととになる。乙のような解 決は社会状態の変化に柔軟に対応するととができる半面、古い意識や政策的判断が無限に浸透するお それがあるてとも指摘されている [利谷，1987，88]。それとともに、「なにが当事者の利益」かを評 価するについてあ、困難な問題が内在する。わたくしはかねてから、家族法は家族構成員の人権を保 障する法であることを説いてきた [有地，1967，1976，1983]。たとえば、子の利益はなにかを評価する 場合にあ、まず該当の子どもの人権を最下限に置き、そのうえで、てれまでの審判例や学説 の集積により判断基準をより精緻するてとがまず必要であろう。さらに、父母による子の奪い合い、ある いは押し付け合いの場合に、父母以外の第三者が子の利益を代表する者として審判手続に参加せしめ ることが必要であるかむしれない(9)。

以上のように、今日の家事紛争の状況之家事事件の処理手続の問題点を指摘して置いたが、新たな 家族の展開に応じて、家事事件処理は種々模索しているというのが現状であろう。

\section{注}

（1）近代的小家族をモデルとする法的家族像が正当なすのとするととから生ずる問題として、利谷信義教授は現 実の多様な家族のあり方からみると、それ以外のあのを差別する結果になることを指摘し、今日では、多様な家族 のあり方に即した適切な選択肢を示すととが今日の法にとって必要と説く（利谷信義，『家族と国家』，筑摩 書房, 1987年, 88頁以下)。

（2）たとえば、扶養に関する審判例は戦後一貫して、中川善之助博士の理論を踏襲し、近代的小家族構成員相互 
摇らぐ家族と家族関係諸法

間の扶養義務をあって生活保持の義務と言い、それ以外の三親等内の親族相互の扶養義務を生活扶助の義務と して、両者を区別する。後者は扶養義務者の余力の範囲内での扶養義務だが、前者は相手方に対して同質同量 の扶養義務を負担するてとになり、モデルとしての近代的小家族を維持する理論である。

(3) たとえば、J.Commaille, Familles sans justice? Le droit et la justice face aux transformations de la famille, 1982, Le Centurion, Paris.が挙げられる。

J. - C. Chamboredon et J. Prévot, "Le Métier d'enfant. Définition social de la prime enfance et fonctions différentielles de l'école maternelle", Revue française de sociologie, XIV, 1973. pp. 295-335.

（4）たとえば、副田義也、利谷信義、依田精一、二宮孝富、庄司洋子、本沢巳个活の諸教授の一連の著書、論文 を挙げることができる。

（5）乙れらの政策は、二宮孝富「最近の家族政策の動向と家族法」「大分大学経済論集」39巻 6 号 (1988年 ), 同，「家族政策及び家族法の動向と今後の課題」「法の科学」16号（1988年）に詳しい。

(6) 乙の点については、有地亨、「現今の相続の機能の変化とその考え方の再検討」「比較家族史研究」 3 号, （1981年）に詳しく述べているので、簡単に指摘するだけにとどめる。

（7）夫婦問の性と法の関係のすぐれた分析として、滝沢聿代「夫婦と性」「法学セミナー」 1989年 2 月号 36頁以下がある。以下では、この論文の示唆を受けるととが多い。

（8）乙の指摘はとくに石川稔教授によってなされている。同「新・家族法事情(7) 離婚交渉と“取引き”」， 『法学セミナー」 1984年11月号66頁以下参照。

(9) 乙の点で、イギリスのマリア・コルウェル事件を素材にして、子の利益代表者の選出の必要を説くあのとし て、南方暁「子どもの福祉とその利益代表者」「法律時報」53巻 5 号 ( 1981年 ) 63頁以下。

\section{文 献}

有地亨、1967，「家族法秩序におりる論理構成」，「法政研究」, 33巻 $3 \sim 6$ 号

有地亨、1976，「現代家族法の構成と基本原理」，「民法学」7, 有斐閣

有地亨、1983，「家族」，「岩波講座基本法学」2, 岩波書店

Chamboredon, J. -C.et Prévot, G., 1973, " Le Métier d'enfant. Définition sociale de la prime enfance et fonctions différentielles de l'école Maternelle", Revue Française de Sociologie, XI , 295-335

人見康子，1980，「第三者の家庭破壊による照謝料」，「別冊判例夕イムズ」8号

星野澄子，1987，「性をめぐる法と道徳と自己決定権」，「思想と現代」 8 号

人口問題審議会・厚生省大臣官房政策課・厚生省人口問題研究所編，1988，「日本の人口・日本の家族」，東洋経 済新報社

Michel, A., 1980, "Critéres, contenu et privatisation de la conception endémoniste de la famille en occident ", Women on the Move: Contemporary Changes in Family and Society, Actes du Meeting d'experts Orgnaise par L'UNESCO a Paris, 25 à 28 Nombre

労働省婦人局編，1988，「婦人労働の実情」（昭和63年版） 
庄司洋子, $1986 \mathrm{a}$ ，「家族と社会福祉」，『ジュリスト増刊総合特集 $41 ・$ 転換期の福祉問題』

庄司洋子，1986 b，「低成長期の家族問題と家族政策」，日本社会事業大学編，『社会福祉の現代的展開 一 高 度成長加ら低成長へ』，勁草書房

総合研究開発機構編，1987，『日本の課題』，三省堂

総理府広報室，1987，「長寿社会」，『世論調査』4月号

利谷信義，1987，『家族と国家』，筑摩書房

上野千鶴子，1985，「家族の前近代・近代・脱近代 一 核家族の孤立をどう脱け出する一」，『世界』，8月号 お断り

1988年夏の家族社会学セミナーでは、時間上の制約で、予定した原稿の 3 分の 1 6発表できなかったため、本稿 は、発表できなかった部を主体に執筆をしたてとを抢話し願いたい。

(ありち・と抢る 九州大学教授) 
The results of our analysis are as follows:

$\mathrm{C}_{1}$ have a conjugal family norm stronger than $\mathrm{C}_{2}$ and $\mathrm{C}_{3}$, though $\mathrm{C}_{1}$ is regarded as a generation which internalized the stem family norm intensely.

Compared with $\mathrm{C}_{1}$ or $\mathrm{C}_{2}, \mathrm{C}_{3}$ have a tendency of more negative attitudes toward the conjugal family norm, though they received individualistic education under which the norm is internalized.

These findings suggest a hypothesis that $C_{1}$ have internalized dual norms, which are composed of different dimensions in Japanese society.

\section{Shaking Families and the Laws for Families}

Toru Arichi

After World War II, Japan's society has been faced with the bustling world and economic trend. And consciousness for families has also changed remarkably. In accordance with that, most of urban office workers have become to form nuclear families. In other side, one parent families, unmarried mothers with children and singles are increasing gradually. That is to say various forms of families have come out. Before, we made efforts to maintain the legal models of "modern small families". However, today we have held a lot of special acts and family policies in regard of various forms of families. For the shaking families at the mercy of these policies, we must reflect how to control the society for families and how should be the families.

\section{Population Policy, Family, and the Problem of the Aged in China}

Keiko Wakabayashi China.

The main objective of this report is to review the population policy in the people's Republic of

The new policy was formally announced in January 1979: "Women who give birth to one child only will be publicly praised, those who give birth to three or more will suffer economic sanctions."

This report shows the complications of the one-child policy, and studies new family problem and implicate China's population in the immediate future and in the next century. 